Cahiers $d u$ MONDE RUSSE

\section{Cahiers du monde russe}

Russie - Empire russe - Union soviétique et États indépendants

40/1-2 | 1999

Archives et nouvelles sources de l'histoire soviétique, une réévaluation

\title{
Svodki and popular opinion in Stalinist Leningrad
}

Lesley A. Rimmel

\section{(2) OpenEdition}

Journals

\section{Electronic version}

URL: http://journals.openedition.org/monderusse/11

DOI: 10.4000/monderusse. 11

ISSN: $1777-5388$

\section{Publisher}

Éditions de l'EHESS

\section{Printed version}

Date of publication: 1 January 1999

Number of pages: 217-234

ISBN: 2-7132-1314-2

ISSN: $1252-6576$

\section{Electronic reference}

Lesley A. Rimmel, «Svodki and popular opinion in Stalinist Leningrad», Cahiers du monde russe [Online], 40/1-2 | 1999, Online since 15 January 2007, Connection on 01 May 2019. URL : http:// journals.openedition.org/monderusse/11 ; DOI : 10.4000/monderusse.11 


\section{$S V O D K I$ AND POPULAR OPINION IN STALINIST LENINGRAD*}

THE RELATION OF PROPAGANDA TO POPULAR OPINION in the Soviet Union has been of interest to scholars for at least half a century, and it will undoubtedly continue to be as long as the question of people's relation to the regime remains an issue. In what proportions did Soviet citizens support the regime, resist it, fear it, or were apathetic to it? How can researchers approach these complicated questions? What are the most useful sources for learning about the Soviet population's perceptions of the regime?

We have not, of course, been without sources on popular opinion for the past fifty years. Archives and émigré interviews in the West, such as in the captured Smolensk archive, the Harvard Project on the Soviet Social System, the Bakhmeteff Archive of Russian and East European History at Columbia University, and the Hoover Institution Archive at Stanford University, as well as published and unpublished memoirs, have provided information on people's outlook, as well as giving us an idea of just what issues absorbed them. All of these sources are useful. But the materials in these collections are insufficient in quantity, recorded events long after the fact, or come from regions that did not include a heterogeneous mix of the population. Newly published or discovered diaries represent an additional source of information on people's beliefs during the Stalin years. ${ }^{1}$ The latter are especially helpful in delineating an individual's personal development over a period of time. Another more recently available - but quickly

\footnotetext{
* I would like to thank Andrea Graziosi and Anatol Shmelev for their comments on earlier drafts of this essay. I am also grateful to the Hoover Institution on War, Revolution and Peace at Stanford University for a Title VIII grant that enabled me to write up this article.

1. See, for example, Jochen Hellbeck, "Fashioning the Stalinist soul: The diary of Stepan Podlubnyi (1931-1939)," Jahrbücher für Geschichte Osteuropas, 44 (1996): 344-373; Veronique Garros, Natasha Korenevskaia, Thomas Lahusen, eds, Intimacy and terror: Soviet diaries of the 1930s, trans. Carol Flath (New York: New Press, 1995).
} 
disappearing - source is that of oral histories and interviews with survivors of the Stalin era. ${ }^{2}$

But these sources - all of which are necessary in order to attempt to create a balanced picture - do not provide the quantity, or variety, needed to make any kind of demographic generalizations, especially about the less educated and less powerful people. ${ }^{3}$ What we do have now (at least in some localities), which we did not have access to before the opening of the archives to foreign and nonCommunist scholars, are official svodki, or reports, on popular dispositions. Perhaps the term svodka is confusing, for these reports varied greatly in their provenance, methods, goals, and reliability. Reports from the secret police, for example, focused on "negative" or dissenting opinions and phenomena, as did those from the Special Sector, Stalin's "secret cabinet," headed by A.N. Poskrebyshev, the Soviet leader's personal secretary (the latter reports mostly monitored party members, the police, the government, and the army). On the other hand, reports from party functionaries, which were collected by the Information Sector of the Department of Leading Party Organs (Otdel rukovodiashchikh partiinykh organov, or ORPO), headed in the mid-1930s by Nikolai Ezhov, aimed at providing a more well-rounded picture of popular dispositions. Unlike the police or the Special Sector, party leaders were not looking for oppositional opinion - on the contrary, it was to their benefit to portray society as supportive of the regime 4 - but functionaries nevertheless could not help encountering "negative" sentiments. Thus the ORPO reports are more reliable in showing oppositional opinion than in demonstrating support for the regime, through no fault of the party representatives who compiled them. The latter wrote their reports largely on the basis of comments made at meetings at factories and farms, but information also came from conversations overheard in shops, trains, and at social gatherings, as well as from written communications, such as graffiti on walls and from leaflets. In addition, reports occasionally drew on denunciations, but compilers of the svodki usually identified such sources, and were not hesitant about appraising their reliability (or lack thereof). 5

2. A recent example are the interviews with schoolchildren of the 1930s in Larry E. Holmes, "Part of history: The oral record and Moscow's model school No. 25, 1931-1937," Slavic Review, 56 (Summer 1997): 279-306.

3. I have also used citizens' letters to the press and to Soviet leaders, but I will not discuss them here.

4. Although reporters also had to demonstrate that they had not become "blinded" to counterrevolutionary activities and that their "revolutionary vigilance" had not become "blunted."

5. See, for example, Tsentral'nyi gosudarstvennyi arkhiv istoriko-politicheskikh dokumentov Sankt Peterburga (TsGAIPD, the former Leningrad Party Archive), f. 24, op. 5, d. 2290, 11. 20, 60 ; f. 24 , op. 5 (ch. III), d. 2714, 1. 121; f. 25, op. 5, d. 44, 1. 9. Here one should mention a peculiarity of the archival system as a whole, and a significant feature of the Soviet regime, as exemplified by its record-keeping - the kul't lichnosti method of archival collection. Which documents were saved seems to have depended on who was in charge of a particular region. This problem was brought home to me by my work in both the former Leningrad and Moscow party archives (TsGAIPD and TsGAOD (Central State Archive on Social Movements), respectively). These two archives did not hold equivalent materials for my topic. While one can 
It might be worthwhile first to look briefly at how some of the svodki I've examined (which here will largely be from ORPO) fit into the (western) historiography of the Stalin era. I do not posit discrete, coherent historiographical schools, but rather stages, or building blocks, and I would break them into four instead of the usual two. What is interesting here is how the materials in the svodki can act almost as Rorschach prints for interpretations of Stalin-era history. One can find aspects of all four of the "stages" in the opinions of Leningraders that made it into the reports. For example, with the first stage, during which what is usually labeled the "totalitarian" interpretation prevailed, and which began in the 1950s and 1960 s, political ideology and the importance of the personality and power of the leader were privileged. Advocates of this interpretation saw 1917 as a breaking point (along with 1902 - the idea of the centralized party - and 1921 - the party's banning of factions), and emphasized the distinctiveness of a type of political system run as a police state, with tight control over the kind of information to which people had access, and in which dissent was not tolerated. ${ }^{6}$ Certainly this latter aspect of the "totalitarian" interpretation is manifest in the svodki, which provide numerous examples of people with "unhealthy" views on a particular subject being hauled off to the NKVD for questioning (or worse). ${ }^{7}$

The second stage of the historiography, which could be termed the "state and society" or social history stage, focused less on ideology and more on the dichotomy between the state and "social forces." This interpretive school first appeared in the late 1960s and early 1970s, although some aspects of it (such as the emphasis on bureaucratism) go back at least as far as Trotskii. Instead of seeing 1917 as a breaking point, it emphasized continuities between pre- and postrevolutionary Russia, such as in the role of the peasantry and its social structure, or

find examples of all manner of "counterrevolutionary" and "negative" opinion in the Leningrad collections, materials for corresponding topics and dates in the former Moscow party archive appear to be non-existant, and in many cases the dela in opisi for what might have been useful materials were marked unichtozheno. My hypothesis on this is that Nikita Khrushchev, having not only survived Stalin but then going on to implement de-Stalinization as well, made sure that potentially harmful records of Moscow under his leadership (1935-1938) did not survive. Leningrad party chief A.A. Zhdanov, on the other hand, having died suddenly in 1948, did not have the opportunity (and probably did not foresee the necessity) for housecleaning in the archives. So much the better for researchers. See also A.N. Ponomarev, "Nikita Khrushchev: nachalo kar'ery (Dokumental'nyi ocherk)," in Neizvestnaia Rossiia XX vek (Moscow: Istoricheskoe nasledie, 1993) $3: 141-142$, for indications that some Khrushchevian documents were indeed burned. Also William C. Taubman, personal communication (June 18, 1997), who reported confirmed evidence that Khrushchev had some of his speeches removed from Ukrainian archives, as well as unconfirmed information from senior Russian scholars that this was so.

6. Examples of writings at this stage include Zbigniew Brzezinski, The permanent purge: Politics in Soviet totalitarianism (Cambridge: Harvard University Press, 1956); Robert V. Daniels, The conscience of the revolution: Communist opposition in Soviet Russia (Cambridge: Harvard University Press, 1960); Robert Conquest, The Great Terror: Stalin's purge of the thirties (London: Macmillan, 1968).

7. E.g., TsGAIPD, f. 25, op. 5, d. 49,1. 132; ibid., f. 25, op. 5, d. 66, 1.90ob. 
the roots of Stalinist rule in the reigns of Ivan IV and Peter I. ${ }^{8}$ On the other hand, this group tended to see discontinuities between Lenin and Stalin, which were caused, variously, by Stalin's personality, the militarizing effects of the Civil War on society, and the growth of the bureaucracy, against which Lenin had railed at the end of his life. ${ }^{9}$ Moreover, at this interpretive stage the rule of Stalin was not considered to be historically determined; alternative paths, such as that proposed by Nikolai Bukharin, were resurrected and even celebrated. ${ }^{10}$ In the svodki from Leningrad, this aspect of the historiography is supported by the numerous examples of people's appreciation for the views of earlier "oppositionists," especially Trotskii. ${ }^{11}$

For some historians, however, there still seemed to be too much emphasis on Stalin and on the power of the center; the rest of the population, both party and nonparty, was either missing or completely passive, and the narrative read rather too much like "When bad revolutions happen to good people." Thus arose the so-called revisionist school, beginning in the late 1970s to the mid-1980s, which challenged the view that Stalin was the only source of the political and social violence of the time; some violent initiatives came "from below" as well, and were not necessarily planned or even encouraged by the regime. ${ }^{12}$ In addition, researchers began to focus not only on who was hurt by the terror, but also on who prospered from it, ${ }^{13}$ and who supported it. ${ }^{14}$ Representatives of this stage of the historiography used a larger source base than had their predecessors, and examined (or re-examined) not only "old" sources such as memoirs, but also the hitherto little-used Smolensk archive, as well as materials from the Hoover and Bakhmeteff archives and the large number of interviews from the Harvard Project. (Numerous excellent studies, many of which are still frequently cited, had already been produced in the 1950 s from the latter project.) ${ }^{15}$ In the svodki, there is ample (if not always obvious) evidence of

8. See, e.g., Robert C. Tucker, Stalin in power: The revolution from above, 1928-1941 (New York: W.W. Norton \& Co., 1990), esp. ch. 1; Moshe Lewin, "Rural society in twentiethcentury Russia," in id., The making of the Soviet system: Essays in the social history of interwar Russia (New York: Pantheon Books, 1985).

9. E.g., Roger Pethybridge, The social prelude to Stalinism(London: Macmillan, 1974); Moshe Lewin, Lenin's last struggle (New York: Monthly Review Press, 1968).

10. E.g., by Stephen F. Cohen, in Bukharin and the Bolshevik revolution: A political biography, 1888-1938 (New York: Oxford University Press, 1973), and "Bukharin, NEP, and the idea of an alternative to Stalinism," in id., Rethinking the Soviet experience: Politics and history since 1917(New York: Oxford University Press, 1985).

11. E.g. TsGAIPD, f. 25, op. 5, d. 49, 11. 85, 100-100ob, 137.

12. For example, J. Arch Getty, The origins of the great purges: The Soviet Communist Party reconsidered, 1933-1938 (Cambridge: Cambridge University Press, 1985).

13. See Sheila Fitzpatrick, "Stalin and the making of a new elite, 1928-1939," Slavic Review, 38 (1979): 377-402, and id., Education and social mobility in the Soviet Union, 1921-1934 (Cambridge: Cambridge University Press, 1979).

14. Robert W. Thurston, Life and terror in Stalin's Russia, 1934-1941 (New Haven: Yale University Press, 1996).

15. For example, Alex Inkeles and Raymond A. Bauer, The Soviet citizen: Daily life in a totalitarian society (Cambridge: Harvard University Press, 1959). 
support for the regime, in addition to abundant examples of the careerism and opportunism that helped the regime to function more efficiently. ${ }^{16}$

Meanwhile, as battles raged between adherents of the first two groups and the third (as well as within "groups," which were not necessarily coherent or welldefined), the situation in the Soviet Union was changing. The policy of glasnost' was allowing for the publication of long-suppressed works, authorities at the highest levels began publishing archival material that touched on some of the "white spots" of history, and oral history and reliable statistics became more widely available. Then, with the August 1991 putsch and the break-up of the Soviet Union, came the opening of the archives to non-party and foreign scholars. These developments sped up the emergence of a growing "resistance" school of Stalin-era historiography, which challenged earlier depictions of Soviet citizens as only victims or supporters of the regime. ${ }^{17}$ These archival events coincided nicely with the growing popularity of post-colonial studies and the works of James Scott. ${ }^{18} \mathrm{My}$ own work thus far might be classified as being a part of this fourth category, and certainly the most thrilling part of reading through hundreds of svodki was seeing so many examples of dissent, resistance, heroism, and plain human decency amidst the opportunism and inhumanity. One's sense of euphoria in coming across repeated instances of "in-your-face" talking back to the authorities, large and small, could probably only be matched by the regime's own paranoia. ${ }^{19}$

Hence, for the historian, there is a constant tension between wanting to give voice to those who have been silenced for so long, on the one hand, and on the other, not painting a picture of more resistance than there actually may have been. This being duly acknowledged, one should thus emphasize the importance of using a wide variety of sources, in order to show the scope of responses to the policies of the Stalin government. The party svodki (much less the police or Special Sector reports) are not the best place to find all of the varieties of opinions, especially ones indicating support for the regime, mostly because in the svodki the "positive," proregime statements - which the reports repeatedly state represent "the vast

16. TsGAIPD, f. 25 , op. 5 (ch. III), d. 2714, 11. 71-72, 87-89, 93.

17. An early example is Lynne Viola, Peasant rebels under Stalin: Collectivization and the culture of peasant resistance (New York: Oxford University Press, 1996).

18. E.g., James Scott, Weapons of the weak: Everyday forms of peasant resistance (New Haven: Yale University Press, 1985), and Domination and the arts of resistance: hidden transcripts (New Haven: Yale University Press, 1990).

19. With regard to the euphoria, one might keep in mind the words of Arlette Farge: “...[I]s there a tendency to attribute overmuch meaning to these archives, emerging as they do from silence; and rather than a reflection of the real, might they not in fact be the oasis for satisfying our own thirst to see the poor and wretched spring to life? [...] Does the seductive influence of the archives risk falsifying or distorting the object being studied?" A. Farge, Fragile lives: Violence, power and solidarity in eighteenth-century Paris, trans. Carol Shelton (Cambridge: Harvard University Press, 1993): 3. On the other hand, as Gábor Támas Rittersporn notes, "Even if the shortcomings and difficulties [mentioned in Soviet official documents] are represented as nothing but fleeting epiphenomena [which, of course, is how they indeed were represented], in reality they happen to be facts of great significance." G. Rittersporn, Stalinist simplifications and Soviet complications: Social tensions and political conflicts in the USSR, 1933-1953 (Chur: Harwood Academic Publishers, 1991): 20. 
majority" of sentiment ${ }^{20}$ - are indistinguishable from the leaden, sloganistic statements printed in the party newspapers (in this case, Leningradskaia pravda). Thus, it is nearly impossible to determine if these statements were genuine; one cannot distinguish from among them the true believers, the opportunists, and the fearful..$^{21}$ The speakers would have had little to lose by publicly parroting the government's propaganda (although perhaps anti-regime coworkers might not have appreciated the voicing of such sentiments, and might have wished to settle with the speakers after the meetings). Even party members were aware that some expressions of support for the regime might have been disingenuous. In one such case, a cleaning woman at the Samoilova First State Candy and Chocolate factory remarked to members of her political literacy circle that "those [women] workers who are weeping over [the assassinated Sergei M.] Kirov just want to get promoted." 22

On the other hand, persons making negative statements - which party functionaries nearly always characterized as being merely otdel'nye or edinichnye - under Soviet conditions of the 1930s would have had little to gain and much to lose from doing so, and thus such statements would not appear to be self-serving. ${ }^{23}$ This, and the earthy, realistic, informal, and often unprintable language of the negative statements lend them an air of believability. ${ }^{24}$ So do their sense of humor, their demonstration of the range and complexity of people's opinions, and their conveying of emotions - love, boredom, frustration - to which one can easily relate, across the decades, miles, and socioeconomic barriers. ${ }^{25}$

20. Or, more precisely, the reports would claim that people supported the regime's policies "edinodushno."

21. This is especially the case for published reports of pro-regime opinion. See Diane Koenker, "Men against women on the shop floor in early Soviet Russia: Gender and class in the socialist workplace," American Historical Review, 100 (December 1995): 1440, where she notes, "It is often difficult to separate the prescriptive reports from the descriptive, difficult to determine when an account represents the party's voice and when it expresses the 'authentic' voice of the shop floor. [...] In evaluating reports of conflicts on the shop floor, one must be perpetually aware that the reports submitted by workers were selected for publication to inculcate values and prescribe behaviors." D. Koenker adds: "Even archival accounts may have been sent up the line worded so as to meet with political approval."

22. TsGAIPD, f. 25, op. 5, d. 46, 1. 34. There may also be an ingenuous, involuntary need for people in general to try to please interviewers and repeat information from news accounts and headlines. See, for example, the analysis of witnesses to the July 1996 crash of Trans World Airlines Flight 800 off the coast of Long Island, New York, "The least dramatic crash witnesses carry the most weight," New York Times (August 17, 1996).

23. Some of the subjects of the reports, on the other hand, would make contrary claims - that anti-regime sentiment was far greater than what could be publicly expressed. For example, according to the calculations of a kolkhoznik in Borovichskii raion, "for every ten who cried [on learning of Kirov's death], one hundred were glad.” TsGAIPD, f. 24, op. 5, d. 2290, 1. 29ob.

24. Ian Kershaw makes a similar point in his assessment of reports of criticial opinion during the Third Reich. I. Kershaw, Popular opinion and political dissent in the Third Reich: Bavaria, 1933-1945 (Oxford: Oxford University Press, 1983): 8.

25 . The statements of impatience and boredom come across especially strongly. 
There are some definite advantages to working with svodki, which permit the exploration of a number of issues that were simply not feasible even ten years ago. We cannot, even now, come up with anything resembling an accurate portrayal of the distribution of opinions among the population. However, if one collects as large a sample as possible, ${ }^{26}$ focusing on statements that appear to have gained nothing for the speaker or writer, on realistically-worded opinions, as well as on reports of arguments, one can find some striking demographic patterns about which groups of people held certain opinions, and why, and under what circumstances, and which issues concerned which segments of the population.

A good example of demographic breakdown can be found in the rumors that occurred in the aftermath of Leningrad leader Kirov's death on December 1, 1934. One especially persistent rumor concerned the latter's purported extra-marital activities, specifically with Milda Draule, the wife of the assassin, Leonid Nikolaev, whose jealous rage then supposedly fueled Kirov's murder. These rumors were long known to western researchers from samizdat memoirs and other émigré sources. Already in 1938 Anton Ciliga was casting doubt on Kirov's marital fidelity, while Elizabeth Lermolo mentioned (if skeptically) the rumor in her 1955 memoir. ${ }^{27}$ The story received its most enthusiastic exposition from Lidiia Shatunovskaia, who stated that "everyone" in "Kremlin society" believed that Kirov was killed because of Draule; the author breathlessly described the alleged fatal scene in Smolny, with Nikolaev barging in on a Saturday afternoon tryst between Kirov and Draule, the latter two then trying to escape down the corridor through a secret door, but ultimately unable to get away from the jealous husband. ${ }^{28}$ Serious analysts, from Roi Medvedev to Dmitrii Volkogonov, have all felt it necessary to discuss the rumor, if only to hypothesize about when and how it was planted..$^{29}$ Mikhail Kheifets wrote that the NKVD released two variants on the story of the Kirov murder, one - that Kirov was killed by a Zinov'evite - for the general population, and another - that the cuckolded Nikolaev killed Kirov out of jealousy - for party circles. ${ }^{30}$

26. How large is "large"? Because the reports were not gathered under objective, "scientific" conditions, it would seem ludicrous to make statements about statistical significance, margins of error, and the like. A more subjective method would be to consider an oppositional opinion "significant" when its repetition becomes monotonous - perhaps after ten times. I simply collected as many examples as possible - as many as time would permit (and as the archive director would allow me to photocopy). And I will try to reproduce as many as editors and publishers will permit.

27. Anton Ciliga, The Russian enigma, trans. Fernand G. Renier and Anne Cliff (London: Labour Book Services, 1940): 171 (the book was originally published in France in 1938 under the title: Au pays du grand mensonge (Paris: Gallimard)); Elizabeth Lermolo, Face of a victim, trans. I.D.W. Talmadge (New York: Harper \& Brothers, 1955): 83, 276.

28. Lidiia Shatunovskaia, Zhizn' $v$ Kremle (New York: Chalidze Publications, 1982): 174-176, 178.

29. E.g., Roy Medvedev, Let history judge: The origins and consequences of Stalinism, trans. Colleen Taylor (New York: Alfred A. Knopf, 1971): 158; Dmitrii Volkogonov, Triumf $i$ tragediia. Politicheskii portret I.V. Stalina (Moscow: Izdatel'stvo Agenstva pechati Novosti, 1989), I, pt. 2: 93-94.

30. Mikhail Kheifets, “Taina zloveshchikh priznanii,” Vremia i my, 70 (1983): 187. 
In fact, if one tracks the progression of the rumor from day to day in the svodki, one can see that the jealousy rumor appeared soon after Kirov's death, and disappeared after the middle of the month. At that point, only the vaguest accusations against class enemies had been made. The stories of Draule, et al., began to disappear just as the accusations against the Zinov'ev opposition appeared in the press on December 18. Thus it is possible that the regime did let out these rumors and, seeing the results, decided to go more quickly in choosing whom to accuse. More interesting, perhaps, is the demographic profile of who actually repeated the romantic liaison story, which tends to confirm Kheifets's version. That is, not only are urban, higher-echelon, largely male speakers (sluzhashchie, party members, students) a plurality in this group (of those mentioning the Draule story), but they are an absolute four-to-three majority - completely out of proportion to their $33 \%$ of the total (of Leningraders making negative statements). ${ }^{31}$ Persons toiling in industry comprise only approximately a third of this group (in contrast to their being greater than one half of the overall total), and peasants are a negligible percentage of those citing personal motives as the reason for Kirov's murder. These results also happen to conform with earlier observations, based on the Harvard Project study of this age cohort, that urban intellectuals were much more likely than workers or peasants to believe rumors over the press. ${ }^{32}$ Non-intelligentsia types, and especially women, were generally less interested in what we might consider "celebrity gossip," and preferred to take on weightier political and economic topics.

This kind of information in the svodki can help historians to redefine the demographic categories they use. Peasant versus worker, or rural versus urban, is a seemingly natural categorization (at least the Soviets thought so). But for the 1930s, this is especially problematic, of course, because of the millions of peasants pouring into the cities. While the identification of speakers by their occupation or workplace location and by their social origin (if known) is useful, I found that these factors were not necessarily the most relevant in influencing people's opinions, despite the continual efforts of party activists to ascribe "unhealthy" opinions to a person's less than optimal "class" background.33 More important was their socioeconomic level. This may now seem obvious, but ten years ago few writers were emphasizing how overwhelming a preoccupation food and shelter were for ordinary people - and not just for those starving in Ukraine or living in caves in Magnitogorsk - during the 1930s, and therefore, how less relevant could be the concerns of western scholars. In Leningrad city and oblast' during the 1930s, the topics of choice were food and shelter and, with regard to the former, the abolition of rationing for bread and related products beginning on January 1, 1935. No matter

31. Or as one party member at the Lenin plant, repeating a story he had heard from others, commented regarding Kirov's alleged iubochnik proclivities, "Had Kirov done less chasing after women, he'd still be alive." TsGAIPD, f. 25, op. 5, d. 45, 1.9.

32. Raymond A. Bauer and David B. Gleicher, "Word-of-mouth communication in the Soviet Union,” Public Opinion Quarterly (Fall 1953): 307 (table 4).

33. See Lesley A. Rimmel, "Another kind of fear: The Kirov murder and the end of bread rationing in Leningrad,” Slavic Review, 56 (Fall 1997): 491. 
how hard party leaders and propagandists tried to keep people focused on more "political" topics such as the conspiracies of enemies, ordinary Leningraders - the mostly non-party people at the lower end of the socioeconomic scale - insisted on bringing the discussions back to earth and voicing their concerns about food prices. Where possible, Leningraders did try to connect their own needs to discussions of enemies, so that e.g. "study" of the exile of "class-alien elements" in 1935 could become an occasion for denouncing possible class enemies in the hope of obtaining vacated housing. In any case, one learns from reading opinions in svodki that economic problems transcended "peasant" or "industrial worker" categorizations, and that one's outlook and ability to empathize with others also transcended such categorizations. ${ }^{34}$

Other demographic classifications that I found to be less useful than expected were partiinost' and age. Active party membership, during the mid-1930s at least, did not imply support for the regime; this was even less true of Komsomol members, who demonstrated a spectrum of attitudes from ardent belief in party goals, to confusion and disillusionment, and to cynicism and opportunism (the tendency for young people to attend Komsomol meetings for the dancing was very pronounced.) $)^{35}$ Likewise, youth generally are difficult to pidgeonhole; they range from party enthusiasts to militant opponents. Their family backgrounds offer little clue to their own opinions; much depended on family dynamics and the individual's own decision-making. Nevertheless, in my samples, youth were disproportionately represented among speakers making "negative" comments, as were both urban and rural "toilers" (as opposed to sluzhashchie) and women. ${ }^{36}$

What exactly constituted a "negative" comment? That this was not always clear - to party members as well as to the general public - lends support to the contention that anti-enemies campaigns, and the propaganda that accompanied them, were usualy not well planned or orchestrated. It was not easy being a party propagandist; no matter how well schooled "instructors" and other party publicists were, they could not finesse propaganda materials that were contradictory, incomplete, or simply made no sense. For example, for three weeks after Kirov's assassination, the regime did not reveal that Nikolaev had been a party member, and thus saying that he was one was considered to be "unhealthy" by the propagandists.

34. See ibid.: esp. 486-489.

35. See, for example, TsGAIPD, f. 24, op. 5, d. 2290, 11. 17, 29ob, 61; f. 25, op. 5, d. 45, 11. 83, 101,102 ; f. 25 , op. 5 , d. 47, 1. 76; f. 25 , op. 5, d. 52, 1. 219. The issue of dancing was already controversial among Komsomol members during the NEP years; see Anne E. Gorsuch, "NEP be damned! Young militants in the 1920s and the culture of Civil War," Russian Review, 56 (October 1997): 574.

36. One has to bear in mind the enormous population changes taking place in the Leningrad region during this time. Thus a longitudinal study of popular opinion might best be thought of as snapshots of particular moments in the life of the region. Significant shifts, such as in the expulsion of what was left of the former aristocracy, the arrest of former opposition members, the removal of invalids and members of the Lumpenproletariat, and the difficult-to-monitor movements of peasants into and out of the city and throughout the various raiony, did bring about shifts in popular opinion as well. 
This did not stop people early on from speculating on it, however: "And why do you think that Nikolaev was a class enemy who by deception wormed his way into the party?" M.A. Alekseeva, a physics teacher in Vasileostrovskii raion, asked a colleague. "It's possible that he was an honest party member who became disenchanted with its policies. It can happen that we waver, for example under the influence of the hunger in Ukraine and the Urals." ${ }^{37}$ Party cell instructors reported being bombarded with allegations of Nikolaev's partiinost', and struggled valiantly to refute them. "What do you mean, was [the assassin] a party member?" was the indignant rebuff of one party member. "Really, such riff-raff could never make their way into the party." 38 Despite the fact that Nikolaev had indeed been a party member, the police were concerned about the frequency of this "rumor's" appearance in the reports, while party cell leaders and propagandists were frustrated by the proliferation of such beliefs and longed for specific directions on how to handle them. The partorg of the city's Institute of Socialist Agriculture, for example, reported that party members and candidates had pleaded for information to counter the growing number of versions circulating among their listeners. "Not knowing the actual situation," the report continued, "it's difficult to give a rebuttal." This was echoed by the partorg of the Electro-Technical Institute, Chapkovets, who asked, "What can I say about the murder of Comrade Kirov that he was killed by the class enemy? - when the papers are silent on the subject; and therefore I am unable to refute and rebuff all manner of rumors on the murder." 39 The party leadership's usual response to such requests was (vaguely) to admonish publicists to improve "mass explanatory work." 40

Even worse for the propagandists, needless to say, were the more obviously "wrong" speculations on the murder concerning Kirov's possible marital infidelity. As the director and party cell secretary of the Leningrad State Academic Theater of Opera and Ballet complained to ORPO, "In view of the generally understandable [sic!] insufficiency of newspaper information about Nikolaev, and about the circumstances connected with the murder, the staff are feeding themselves on all kinds of rumors." 41 Likewise, in the days before any information on Nikolaev was provided, the secretary of the Krasnogvardeiskii raion cell wrote, with exasperation, "The raikom especially points out the necessity of the decisive unmasking of counterrevolutionary conversations about how the murder of Comrade Kirov was motivated on personal grounds." ${ }^{2}$ Such laments from party

37. TsGAIPD, f. 25 , op. 5 , d. $45,1.94$.

38. Ibid., f. 25 , op. 5, d. 52 , 1. 137. See also ibid., f. 25 , op. 5 , d. 44, 1. 14; f. 25, op. 5, d. 47 , 1. 103 ; f. 25 , op. 5 , d. $51,1.40$; f. 25 , op. 5 , d. 52 , 11. $158 \mathrm{ob}, 194,196$.

39. Ibid., f. 25 , op. 5 , d. $45,1.110$.

40. Apparently this response had been typical since the earliest days of Soviet history. See, e.g., L.A. Molchanov, "Neobkhodimo usilit' propagandu," Istoricheskii arkhiv, 4 (1996): 193.

41. TsGAIPD, f. 25, op. 5, d. 46,1. 105 (December 5); again, it tended to be those not employed in physical labor who expressed the most interest in rumors.

42. Ibid., f. 24, op. 5, d. 2291, 1. 56. 
organizers underscore the reliability of the svodki; these are not examples of the false modesty of ritualistic and difficult-to-interpret samokritika, but rather of genuine anguish.

Audiences on either side of an issue were quick to catch inconsistencies in whatever happened to be the government's current narrative. A common reaction to announcements of newly-discovered "enemies" throughout the 1930s was disbelief and indignation - not necessarily because of support for the accused, but because people wondered why the government had taken so long to "uncover" them, or had missed earlier opportunities to punish them. "If the Zinov'ev opposition was active here," queried a worker at Red Instrument-maker on December 17, 1934, when Zinov'ev and his associates were first publicly implicated in Kirov's murder, "then why wasn't he exiled at the same time with Trotskii [in 1929]?"43 This would be a constant refrain for the next several years. ${ }^{44}$

Moreover, Leningraders were getting two messages about enemies, and instructors were utterly confused as to how to respond. News articles in Leningradskaia pravda stressed orderly procedures. For example, on December 23, the NKVD announced that Zinov'ev, Kamenev, and other members of the newlystyled "Moscow Center" had been arrested and that their cases would be given to the NKVD Special Board, with a recommendation of administrative exile, as not enough "evidence" had been found for a trial at that time. But editorials in the newspaper, on the other hand, painted a much more sinister picture. Just the day before, on December 22, readers had seen Zinov'ev's name linked with Nikolaev's in the editorial "Vile murderers," on the front page along with an announcement from the NKVD that Nikolaev's case had been transferred to the Military Collegium of the USSR Supreme Soviet - understood as a one-way ticket to oblivion. ${ }^{45}$ Thus, for example, at the Second Five-Year-Plan plant, Fillipov, a specialist, puzzled, "It's hard to make sense of it all. The leading piece in Leningradskaia pravda for December 22, 'Vile murderers,' leads us to believe that Zinov'ev and Kamenev should receive the same punishment as the other murderers." 46 One factory party secretary, Stepanova, wrote that she had had great difficulty explaining the possibility of exile to her workers, all women, so great was the clamor for shooting. ${ }^{47}$ Thus too much "agreement" with the regime's messages was just as problematic as outright disagreement.

43. Ibid., f. 25 , op. 5 , d. $49,1.67$.

44. Ibid., f. 25, op. 5, d. 48, 1. 33; ibid., f. 25, op. 5, d. 49, 11. 46, 66, 67; f. 25, op. 5, d. 50, 1. 28. However, here it would be good to have an actual audio recording of such comments; perhaps people were speaking sarcastically, although reports often indicated if this was the case.

45. E.g. ibid., f. 24, op. 5, d. 2715, 1. 4, where a worker at the Baltic plant remarked, "If people end up at the Military Collegium, it usually means they'll be shot." See also Peter Solomon, Soviet criminal justice under Stalin (Cambridge: Cambridge University Press, 1996): 263, n. 88, citing Anton Antonov-Ovseyenko, The time of Stalin: portrait of a tyranny (New York: Harper \& Row, 1981): 150, on the Military Collegium's frightful reputation.

46. TsGAIPD, f. 25 , op. 5 , d. $49,1.124$.

47. Ibid., f. 25, op. 5, d. 49, 1. 119; also f. 25, op. 5, d. 48, 11. 12, 14ob, 20, 35, 37, 41, 43, 46, 51. 
This became especially clear after the verdicts of the in camera trial of the "Moscow Center" of Zinov'ev, et al., were published on January 18, 1935. The build-up since mid-December had been intense, and by the day of the announcement, the newspapers were full of such shrill headlines as "The workers of Leningrad demand the strictest punishment for the vile traitors." 48 Thus to some Leningraders, the sentences did not seem to correspond to the crimes. The investigation could not establish a criminal case against the Moscow Center in the slaying of Kirov, but could only confirm that members of the Moscow Center "knew about the terrorist inclinations of the Leningrad group and had themselves [helped] stir up those inclinations." 49 Therefore, the "proletarian court" (the Military Collegium of the USSR Supreme Court, it turned out) assigned punishments of ten years' imprisonment to Zinov'ev and three others, with the rest getting five to eight years. The newspaper's announcement - entitled "Proletarian verdict" - assured readers that "the toilers of our land will greet this verdict with unanimous approval."

Yet this was hardly the case. There were numerous examples of people (often older workers) who stood up for Zinov'ev or other former leaders, as well as those who, on the contrary, felt that the "Moscow Center" was being treated too leniently. In an example of the latter case, a worker, Gorelov from the Marti plant, stated, "If [the Zinov'ev group] isn't liquidated, then the court will be violating the government's decrees on traitors." 50 Propagandists were placed in an awkward position when members of their audiences, such as the worker Razguliaev of the OGPU plant, complained:

"Yesterday [i.e., January 17] we held meetings about the publication of the indictment, in which we demanded merciless reprisal against the class enemy, and today the press tells us that the proletarian court has given a sufficiently harsh punishment to the ideological inspirers of the class rags. They should get what they deserve." 51

Speakers who felt that the "Moscow Center" members were getting off easy often pointed out the unfairness of "the big guys" being left alone, while "small fry" were executed: "They give a cabby ten years for theft, and these scum also get ten years," a worker from Red Instrument-maker asserted.52 Others, with a touch of local boosterism, seemed resentful that the "Leningrad Center" was being punished more harshly than the "Moscow Center." Because workers' calls for execution of enemies were such a staple of the propaganda of the 1930s, the possibility that these were government-generated responses in disguise cannot be discounted. But the propagandists themselves always categorized these statements as "negative" or

48. Leningradskaia pravda (January 17, 1935).

49. Ibid.

50. TsGAIPD, f. 24, op. 5, d. 2715,1. 11.

51. Ibid., f. 25 , op. 5, d. $65,1.60$.

52. Ibid., f. 25, op. 5, d. 48, 1.65 . 
"unhealthy," sending examples of these along with statements supportive of oppositionists on to the NKVD, and they stressed how much work they put into trying to explain how well the sentences fit the "crimes." Svodki thus can provide an illuminating portrait of propagandists engaged in the mental (and emotional) gymnastics necessary to keep up with the regime's ever-changing interpretations of events. ${ }^{53}$

As noted earlier, however, svodki are generally not the best place to find reliable instances of pro-regime opinions; they are largely non-existent in NKVD and Special Sector files, and the examples given in the ORPO files are usually too stereotyped to decipher. But in the latter there are exceptions. For example, believable as pro-regime comments are praises to the leaders - for the wrong reasons. It is difficult to tell if workers' echoes of the newspapers' depiction of the slain Kirov as the "truest son and most beloved leader of the Bolsheviks" are heartfelt. But what do appear to be genuine are the numerous expressions of grief for Kirov based on national chauvinism and anti-Semitism. For instance, the worker Zotin at the Stroiprom Association commented, "There, you see, what scoundrels - amid the leaders there was one Russian, Comrade Kirov, and that's the one they killed." 54 Usually connected to the nationality issue were praises of Kirov at the expense of Stalin, or occasionally of Kaganovich. "Too bad about Kirov, since he was Russian; it would have been better to have killed Stalin," stated Komsomolka Levina of the Red Instrument-maker plant. ${ }^{55}$ But not all "unhealthy praise" came on the basis of nationality; Kirov did have some real admirers, such as Gorshkov, a worker in the foundry section of the Pirometr plant, who was obviously not trying to score any points with the powers-that-be when he mused, "It would have been better to have killed Stalin, but it's too bad about Kirov; Kirov loved the poor." 56 Thus through such backhanded compliments can the researcher find honest attempts to differentiate from among the leadership - although far more common than these were blanket condemnations.

Another place to find believable pro-regime comments (and nuanced opinions) in the svodki are in the reports of interactions and face-to-face encounters that

53. The authorities were well aware of this problem, and of the skepticism of some Leningraders. The NKVD reported that a history teacher, Laski, at school no. 10 in Kirovskii raion, criticized the hypocrisy of his fellow teachers, whose interpretations, like that of the party instructors, changed with the political winds: "The history you claim to be teaching is worthless. At one time everyone was singing Zinov'ev's praises, and his books were published in great quantity, and now they're putting him away for ten years. To tell the truth, if you compare Zinov'ev's works with those of certain other leaders, then Zinov'ev comes out ahead." TsGAIPD, f. 24, op. 2v, d. 1188, 1. 165. The NKVD concluded here that there were still too many "alien elements" among schoolteachers.

54. Ibid., f. 25, op. 5, d. 44, 1. 8; also ibid., 1. 6; ibid., d. 47, 1. 43. Of course, Kirov was not the "only Russian," but some Leningraders were not especially accurate in their characterizations of the leaders' backgrounds.

55. Ibid., f. 25, op. 5, d. 47,1. 162. Also ibid., d. 44,1.70; d. 45,1.112; and d. 47,1. 45.

56. Ibid., f. 25, op. 5, d. 47, 1. 43. A reader of the report had marked "K.R." in especially heavy pencil alongside this remark. See also ibid., 1. 104; d. 45, 1. 104; d. 52, 1. 127ob (for a bookkeeper, Ostrovskaia, expressing the "soft" Kirov thesis). 
illustrate different sides of an issue. Sometimes these reports confound the usual stereotypes of various kinds of people. For example, in a discussion among members of a two-month-old kolkhoz in the village of Borisovo, in Ustiuzhenskii raion, the highest-ranking member was the most anti-Communist - who was also considered to be the most lazy. The latter, Nikolaev, who was the kolkhoz president, and a group of kolkhozniki and edinolichniki were talking as they worked at a mill. Nikolaev, commenting on Kirov's murder, observed, "One has been killed; they should all be slaughtered. They've tortured the peasant long enough. Look how they used force to drive us into the kolkhoz, and now we'll die from hunger." But an unidentified woman retorted, "Why are you trying to agitate - you're talking complete nonsense. Look, in our kolkhoz we get 7 kilograms of bread for the labor-day; yet you say you'll croak from hunger in the kolkhoz. You're an idler, that's what." To which Nikolaev responded, "Don't boast; we only know that there's no way out - there's no alternative to [the Communists'] authority. We have to endure it while we still have endurance left." 57

Other reports of face-to-face confrontations confirm what one might expect about the generation and gender gaps of the Stalin years. One such example came from a young candidate party member, Fedorova, who reported in great detail to her deputy party organizer, Bushtyrkov, on her ineffective attempts to explain the truth about Trotskii and Zinov'ev to a group of mostly older, skilled workers at the Kirov plant. They had argued about Trotskii's "Lessons of October" and about the latter's role in the revolution; one of the workers, Bakhmut'ev, asserted for example that if there had been no Trotskii, there would be no Soviet Union. A recent graduate of the factory-plant school, Rastigaeva, admonished Fedorova, "Don't you meddle if you don't know what you're talking about - listen to your elders." Fedorova ran into the group a few days later, and the debate over the relative contributions of Stalin and Trotskii to the October Revolution continued. Mikhail Smirnov, a marker, termed the recent accusation against Zinov'ev "preposterous," and compared it with the Nazis' having blamed a Communist for starting the Reichstag fire. "And likewise," Smirnov added, "in the villages they're clamping down on kulaks; for example, in the village where I lived, there was a fire for which they blamed the kulaks. But kulaks weren't guilty; the fire was caused by carelessness." More arguments ensued; Rastigaeva called the Komsomol a "riff-raff" organization, and added unsisterly insult to injury by advising Fedorova to get married and not waste her time with the Komsomol. ${ }^{58}$

Thus despite the party's continual efforts to use older workers for propaganda purposes (to compare the "bad old days" with the present), there were other older, skilled workers to counteract the "official" ones. Moreover, migrants from the

57. Ibid., f. 24, op. 5, d. 2291,1.32a. Seven kilograms per labor-day was considered to be quite high. See V.A. Seleznev and A.Ia. Starikova, Kollektivizatsiia sel'skogo khoziaistva v severozapadnom raione (1927-1937 gg.) (Leningrad: Izdatel'stvo LGU, 1970): 17; and Sheila Fitzpatrick, Stalin's peasants: Resistance and survival in the Russian village after collectivization (New York: Oxford University Press, 1994): 31 (on “idlers”), 146.

58. TsGAIPD, f. 25, op. 5, d. 49, 11. 100-100ob. 
countryside, such as Smirnov, were not always ignorant of world events, and were a source of information and networking between countryside and city. Meanwhile, the young, hapless, and not terribly well respected party candidate Fedorova, unsuccessful in her propaganda effort, channeled her frustration by denouncing the group as an "anti-party" circle. The people involved found out about it, and told her, "The time will come and we will settle accounts with you." ${ }^{9}$ One can easily see here the kinds of confrontations that would provide fodder for more deadly actions in the future.

At this point one should mention the important role of old sources, such as memoirs, in providing believable examples of pro-regime opinion. "Old sources" helped to establish the very topic of the terror. Apart from these works, there was little other information on the victims of state violence under Stalin (and under the Communists generally), and certainly not from the victims' point of view. And even had complete and reliable figures been published detailing the number of people arrested, exiled, sent to camps, or shot - along with information on what became of all their family members - we would not have had a very compelling or memorable picture of the terror. ("When one man dies it's a tragedy. When thousands die it's statistics," Stalin reportedly told Winston Churchill.) ${ }^{60}$ "Labor camp," "cold," "lice" - these words might mean little without the skillful and penetrating accounts of such writers as Evgeniia Ginzburg, Mariia Ioffe, and Varlam Shalamov, ${ }^{61}$ to name just a few, who were able to impress upon the reader, if only temporarily, the horrors that these people faced. As one gets deeper into one's research, there is a temptation to become submerged in the minutiae and the mass of details, and the danger of overintellectualizing the topic becomes real. Thus, it is helpful - and necessary - to read another memoir from time to time. And one can glean useful information on attitudes from the best of the memoirs.

The limitations of such memoirs are well known. Authors' individual biases must be taken into account, as well as that of their milieu. Nadezhda Mandelstam, for instance, may have written of "the whole country," when in fact she could at most claim to speak for a small, if important, group of the USSR's leading artists and intellectuals. ${ }^{62}$ Thus memoirs can provide invaluable descriptions of specific times, places, and events that the authors themselves experienced. But a larger context is often lacking, and observations relevant to one segment of society may be irrelevant to others. Former or current Communists rarely ask "why" or "how," and few query themselves on why and how they earlier managed not to notice the

59. Ibid., f. 25 , op. 5 , d. 48, 1. 11.

60. A. Antonov-Ovseyenko, op. cit.: 278 (citing an incomplete reference to Churchill's The Second World War).

61. E.g., Evgeniia Semyonovna Ginzburg, Journey into the whirlwind, trans. Paul Stevenson and Max Hayward (New York: Harcourt, Brace and World, 1967); Mariia Ioffe, Odna noch'. Povest' o pravde (New York: Khronika, 1978); Varlam Shalamov, Kolyma tales, trans. John Glad (New York: W.W. Norton \& Co., 1980).

62. Nadezhda Mandelstam, Hope against hope: A memoir, trans. Max Hayward (New York: Atheneum, 1970): 316. 
regime's abuses, when they were inflicted on "other" people. ${ }^{63}$ Finally, émigré accounts may be biased in that refugees often have to psychologically justify to themselves the often wrenching decision to leave native land and language, especially when a return is out of the question, and thus one would expect them to emphasize only the negative aspects (which would not be difficult). Interestingly, this did not appear to be true of the Harvard Project interviewees, many of whom seemed to appreciate the educational opportunities they received in the Soviet Union. Another problem with memoirs, testimonies, and such is that they do not always address the same issues, and thus there are not enough of them to construct convincing arguments as to the prevalence of a particular view. Quantity does matter.

But, again, old sources such as memoirs can be useful in attempting to locate bases of support for the regime. Because, as noted earlier, the extent of pro-regime views is sometimes difficult to determine from the Leningrad svodki, memoirs can fill an important gap. As with the svodki, it is important to consider what the speaker or author had to gain by expressing a certain opinion. If there was no benefit to the speaker, then the statement would tend to have greater credibility. Thus one of the best places to find genuine agreement with Soviet policies of the 1930s might be in the memoirs of those who later became dissidents (for example, Petro Grigorenko, Lev Kopelev, or Aleksandr Solzhenitsyn. ${ }^{64}$ By the 1950s, such people would have had nothing to gain by portraying themselves as having been loyal to Stalin or to Communism. It is possible, of course, that latter-day dissidents may have had doubts even while in the thick of helping to execute Soviet policy in the 1930s, and later glossed over or forgot having had these doubts because of guilt at not having acted on them. But this seems less likely; many memoirs from former dissidents appear to have been an honest attempt at raskaianie for the naïve enthusiasms of youth. A good counter-example which illustrates this point is provided in Michael David-Fox's analysis of Abdurakhman Avtorkhanov's autobiographies, which turn out to be inconsistent with archival records. As DavidFox notes, Avtorkhanov would have had plenty to lose in the 1950s, when he was employed by the United States, in portraying himself as having once been a "true believer." 65 This denial of his actual beliefs at the time of the first Five-Year Plan corresponds with the discrepancy in his account of his whereabouts, and therefore his understanding of the situation, at that time. Thus one has to be especially careful with memoir accounts that portray the author as having been engaged in dissent

63. See, e.g., Irina Alekseevna Efimova, "Zhena vraga naroda," unpublished manuscript, Scientific and Information Center of "Memorial," St. Petersburg, Russia.

64. Petro G. Grigorenko, Memoirs, trans. Thomas P. Whitney (New York: W.W. Norton \& Co., 1982); Lev Kopelev, The education of a true believer, trans. Gary Kern (New York: Harper \& Row, 1980); Aleksandr I. Solzhenitsyn, The Gulag Archipelago, 1918-1956: An experiment in literary investigation, trans. Thomas P. Whitney (New York: Harper \& Row, 1974).

65. See Michael David-Fox, "Memory, archives, politics: The rise of Stalin in Avtorkhanov's Technology of power," Slavic Review, 54 (1995): esp. 995-996. 
when it was dangerous to do so. Memoirs often shed more light on the era when they were written than on the time they are supposed to be describing.

Nevertheless, there is much agreement between old sources and new ones, especially party svodki. This is especially true of materials from the Harvard Project and from the Bakhmeteff Archive. For example, in "The story of a Leningrad worker" from the Bakhmeteff Archive, the worker, Peter Stoilov, voices the same complaints that repeatedly occurred among workers in the TsGAIPD svodki, such as those concerning all the "voluntary" donations of labor and money that workers were pressured to make (especially in the mid-1930s). Another worker, Anna Ivanovna M., likewise spoke of her dislike of all the political meetings workers were obliged to attend during the lunch break and after work. The TsGAIPD files are filled with similar expressions of annoyance. ${ }^{66}$ Among the subjects of the Harvard Project, there were numerous examples of those who, like their counterparts in the Leningrad svodki, felt that many people merely pretended to believe in the government's propaganda in order to get ahead. ${ }^{67}$

Svodki cannot tell the whole story of events and opinions in the 1930s. But the whole story cannot be told without them. ${ }^{68}$ Using svodki it may not always be possible to follow the trail of one particular person throughout the decade; ${ }^{69}$ they are perhaps more useful for an "archeology of knowledge."70 But if svodki do nothing else, they help to humanize an often inhumane era. Statistics become people with names, histories, and strong opinions. These people often resist being categorized - either by the regime that claimed to rule in their name, or by latterday scholars claiming to speak for them. Their concerns often had little to do with the concerns of researchers, but their sorrows, and their laughter, can reach readers many years later. Ascertaining the veracity of government svodki will always be an art, not a science, that must be informed by one's knowledge of the era and supplemented by other kinds of sources. But a close examination of svodki rewards

66. Bakhmeteff Archive of Russian and East European History and Culture, Columbia University, David Dalin file, "Story of a Leningrad worker," 6; Anna Ivanovna M., 4; TsGAIPD, e.g. f. 25, op. 5, d. 44, 1. 14; ibid., d. 45, 1. 108; ibid., d. 46, 11. 52, 135, 151; ibid., d. $50,1.7$.

67. Harvard Project on the Soviet social system, Schedule A, vol. 3, no. 25: 25, 27.

68. Another example of the usefulness of svodki is in helping to trace the origin of a particular decree. In one instance, the Leningrad NKVD, reporting to local party chief A.A. Zhdanov on the need for greater control of the population's movements in and out of the city, proposed remedies which became the basis of a Leningrad oblast' party bureau decree on May 17, 1935 . Here one can clearly see the heavy influence of the police on Communist Party policy at this time. (The original report is in TsGAIPD, f. 24, op. 2v, d. 1188, 11. 70-71; the decree is in Rossiiskii tsentr khraneniia i izucheniia dokumentov noveishei istorii (RTsKhIDNI), f. 17, op. 21, d. 2722, 11.63-64. The wording of much of the report and of the decree is identical.)

69. Although occasionally one can find a petition or letter to a leader protesting a denunciation that one first came upon in a report.

70. To borrow the title of one of Michel Foucault's less frequently-cited works, The archeology of knowledge (New York: Pantheon, 1972). 
the researcher by revealing a multifaceted society, much of it at odds with the regime and, eventually, increasingly at odds with itself.

Oklahoma State University

College of Arts and Sciences

Department of History

501 Life Sciences West

Stillwater Oklahoma 74078-3054

e-mail:1rimmel@okway.okstate.edu 